\title{
Cancer Stem Cell as Target of CAR-T Cell Therapy
}

\author{
Xinran $\mathrm{Li}^{1}$ \\ ${ }^{1}$ Division of Biological Sciences, University of California, San Diego, San Diego, CA, US
}

\begin{abstract}
Chimeric antigen receptor-T cell (CAR-T) therapy has been studied intensively these years and is considered a promising cancer treatment. So far, Food and Drug Administration has approved 2 CAR-T cell therapy for patients with refractory leukemia and the result is positive. However, CAR-T cell therapy is still facing several challenges, including antigen escape, which will diminish the efficacy of treatment and lead to relapse. This review investigates the potential of cancer stem cell (CSC), a small group of cancer cells that contribute to tumorigenesis, metastasis, therapy resistance and relapse, as the target of CAR-T cell therapy, focusing on representative CSC surface markers: CD123, CD133 and CD44. Evidence indicates that CAR-T cell therapy directed by CSC surface markers is effective and feasible. Therefore, CSC targeted CAR-T cell therapy is a prospective treatment for cancer.
\end{abstract}

\section{Introduction}

Chimeric antigen receptor- $\mathrm{T}$ cell (CAR-T) therapy is a promising cancer treatment. CAR-T cells are genetically engineered $\mathrm{T}$ cells consisting 3 parts: an extracellular antibody-like surface domain, a transmembrane domain and an intracellular signaling domain 1. The extracellular part responsible for antigen recognition is made of singlechain variable fragment( $\mathrm{scFv})$ targeting specific tumorassociated antigen (TAA)2. CD19, a highly and frequently expressed surface marker on B-cell leukemias and lymphomas, is one of the most common antigens targeted by CAR-T1. The transmembrane domain derived from $\mathrm{CD} 3-\zeta, \mathrm{CD} 4, \mathrm{CD} 8$, or CD28 molecules connects the extra- and intracellular domains 3 . For the currently approved CAR-T cell therapy, the intracellular signaling domain containing a costimulatory domain (CD28 or 4$1 \mathrm{BB}$ ) and the $\mathrm{CD} 3 \zeta$ chain activates the cell1. The CAR-T cell therapy is highly customized, collecting the T cells from the patient, genetically modifying them into CAR-T cells and injecting CAR-T cells back to the patient4. As a "living drug", the CAR-T cells would multiply in the patient's body, recognize and kill the cancer cells that they recognize 5.

CAR-T cell therapy has moved far beyond an experimental theory in the laboratory and launched successfully as a revolutionary treatment into clinical use. Up to date, FDA has approved two CAR-T cell therapy: Kymriah for patients up to 25 with B-cell precursor acute lymphoblastic leukemia (ALL) and adult patients with relapsed or refractory $(\mathrm{r} / \mathrm{r})$ large B-cell lymphoma and Yescarta for adult patients with relapsed or refractory large B-cell lymphoma67. Both treatments demonstrate auspicious result: Kymriah has an overall response rate (ORR) of $50 \%$ and Yescarta has an ORR of $72 \% 67$. This novel therapy certainly brings hope and health to many patients who have suffered for years. Because of its success, the field studying CAR-T cell therapy is blooming and the public are looking forward to its performance in treating other types of cancer.

Despite its current promising outlook, CAR-T cell therapy still has various problems that need to be overcome as it advances into treating solid tumors. One of the major challenges is the relapse caused by antigen escape. In an ideal situation the TAA used for CAR-T cell therapy are expected to be expressed by all the cancer cells, but unfortunately, as scientists make further progress in the field, it is discovered that with the persistent presence of CAR-T, the expression rate of the TAA decrease and the ratio of tumor cells without the TAA increase8. One of the current approaches is identifying other potential target, for instance the dual targeting of CD19 and CD123 shows promising outcome9. CD123 is a cancer stem cells surface marker and the current success raises cancer stem cells, a subpopulation of tumor cells, as potential targets for CAR-T therapy because of their stem cell like characteristics and their contribute to tumorigenesis and relapse10. In this review, we discuss cancer stem cells as potential targets for CAR$\mathrm{T}$ cell therapy and summarize the result of current experiments on CAR-T directed by CD123, CD133 and CD44, all of which are expressed across various types of cancer as indicated by Table 1 .

Table1. Prevalence of CSC markers CD123, CD133 and $\mathrm{CD} 44$

\begin{tabular}{|c|c|}
\hline $\begin{array}{c}\text { Surface } \\
\text { marker }\end{array}$ & prevalence \\
\hline CD123 & hematologic malignancies \\
\hline CD133 & $\begin{array}{c}\text { hepatocellular carcinoma, pancreatic } \\
\text { cancer, brain tumor, breast cancer }\end{array}$ \\
\hline
\end{tabular}




\begin{tabular}{|c|c|}
\hline CD44 & $\begin{array}{c}\text { leukemia, hepatocellular carcinoma, } \\
\text { lung cancer, ovary cancer }\end{array}$ \\
\hline
\end{tabular}

\section{Cancer Stem Cells (CSCs) Characteristics}

As the name suggests, CSCs demonstrate stem cell characteristics: self-renewal and differenciation11. They also contribute to cancer metastasis and show resistance to chemotherapy and radiation therapy 11 . Self-renewal allows the preservation of CSCs through mitosis and differentiation allows CSCs to generate bulk of tumor cells and enlarge the tumor12. Metastasis is caused by circulating tumor cells: tumor cells that are shed from the original tumor into the circulatory system, can seed at a different site and develop into a new tumor13. Some of the circulating tumor cells express cancer stem cell surface markers and are highly tumorigenic 14 . With their multi-layers self-defense lines and the ability to rapidly repair DNA, CSCs are considerably more resistant to chemo- and radio- therapy compared with normal tumor cell and would relapse1516. These characteristics indicate that CSCs play a significant role in the development of tumor, the resistance to clinical treatment and the relapse of cancer. They also imply that CSCs are useful targets for cancer therapy because once CSCs are removed, the severity of tumor would decrease remarkably.

\section{CD123 as Target}

Previous studies have shown that CD123, also known as interleukin-3 receptor alpha chain, has been overly expressed in hematologic malignancies, including acute myeloid leukemia (AML) and B-cell acute lymphoblastic leukemia and the presence of CD123 is always associated with poor prognosis. Previous works conducted by $\mathrm{Dr}$ MUÑOZ from Hospital de la Santa Creu i Sant Pau, Spain, analyzed CD123 expression in patients and 43 out of 45 patients with AML and all 13 patients with B-cell ALL were positive for CD12317. The expression was homogenously on blast tumor cell with moderate intensity 17. Another experiment on AML indicates that CD123 is highly co-expressed with CD34 and that CD123 plays a significant role in the initiation and maintenance of leukemia population18. Patient with higher rate of CD123 have a significantly lower number of remission and higher number of relapses compared with patient with lower rate of CD12319. Because of its wide presence and negative impact on patient with AML, CD123 is a potent target for CAR-T cell therapy and is becoming a new focus for research.

In the past decade, scientists have targeted CD123 with CAR-T cell therapy, either by itself or with another TAA. The results suggest that CD123 CAR-T is able to target and eliminate primary AML cells in vitro and in vivo and the survival rate of mice with AML treated by CD123 CAR-T is significantly higher than those treated with phosphate-buffered saline (PBS) or CD19R T cells20. Another group took a different approach and designed and anti-CD123 CAR cytokine - induced killer (CIK) cells, a specific type of T cells with natural killer cell like phenotype21. The ability for anti-CD123 CAR CIK to target and kill AML cells was also good and this approach appeared to have lower side effect as antiCD123 CAR CIK showed limited activity towards normal cells with low CD123 expression21. A research conducted in 2014 on CD33 CAR and CD123 CAR also confirmed that CD123 CAR was effective in killing AML blasts and expressed less damage to normal hematopoietic stem/progenitor cells compared with CD33 CAR22.

CD123 has also been used together with another surface marker, CD19. Researchers have tried dual CD123 and CD19 targeting T cell to prevent the relapse caused by antigen loss after the treatment of CD19 CAR T9. The research noticed that B cell ALL cells expressing CD123 were not eliminated by CD19 CAR T and were responsible for the antigen loss relapse9. Mice model with B-ALL has shown that while those received only CD19 CAR T expressed progression of CD19-negative tumor cells, the ones that received CD19 CAR T and CD123 CAR T showed no sign of disease9. All the success that have achieved in CD123 CAR T imply that CD123, either by itself or as a supplement for another TAA, is a worthy target for further investigation.

\section{CD133 as Target}

Scientists have studied CD133 as a cancer stem cell marker extensively in the past decades and learned that CD133 is prevailing in various types of cancer, including hepatocellular carcinoma23, pancreatic cancer24, brain tumor 25 and breast cancer26. CD133 contributes to tumor initiation 25 , metastasis, and drug resistance 26 and high level expression of CD133 indicates poor prognosis27. Previous study demonstrates that CD133 is tumorigenic: $1000 \mathrm{CD} 133+$ medulloblastoma cells injected to mice model lead to development of tumor and differentiation in tumor cells while 105 CD133- cells did not form tumor25. In a clinical analysis of patients with breast cancer, CD133 is found to be positively associated with tumor size and lymph node metastasis28. CD133+ CTC from breast cancer were enriched after chemotherapy while CD133- CTC decreased dramatically, indicating that CD133 contributes to chemoresistance29. Previous analysis of 723 patients with pancreatic cancer showed that patients with overly expressed CD133 had significantly lower survival rate compared with those who has low CD133 expression27. In summary, the prevalence of CD133 across different types of cancer and its contribution to tumorigenesis, metastasis, chemotherapy resistance and poor prognosis make CD133 a significant target for cancer therapy.

CD133 directed CAR-T cell therapy demonstrated its practicability and effectiveness in the lab and in a phase I clinical trial3031. Dr Parvez Vora and his team constructed 3 different approaches targeting orthotopic xenograft glioblastoma cells, anti-CD133 immunoglobulin G, CD133 dual antigen T cell engager, and CAR-T CD133, and compared their anti-tumor 
ability31. The result indicates that CAR-T CD133 had the strongest power in inhibiting the development of cancer and the treatment showed no acute toxicity against normal cells expressing CD13331. The phase I clinical trial enrolled 14 patients with hepatocellular carcinoma, 7 patients with pancreatic carcinomas, and 2 patients with colorectal carcinomas and their cancer were in advanced stage, reoccurred after lesion and showed metastasis 30 . All patients received an initial four-week treatment cycle and could continue the treatment if it was beneficial to their condition 30 . The actual treatment ranged from 9 to 63 weeks for different patients and outcome was desirable: 3 patients achieved partial remission, 14 patients had a stable disease period for 9 weeks to 15.7 months and 3 patients had continuous response to the treatment 30 . Because of its success in the clinical trial, CAR-T CD133 demonstrates future potential in treating advanced metastasis malignancies and in treating solid tumor with CAR-T.

\section{CD44 as Target}

CD44 is widely expressed across different types of cancers, including leukemia32, hepatocellular carcinoma33, lung cancer34, and ovary cancer35. Similar to the previous CSC surface markers, CD44 plays critical roles in drug resistance36. In leukemia, enhanced CD44 in mouse and human T-ALL cell lead to enhanced chemoresistance while CD44 knockout lead to chemosensitivity36. The high expression of CD44 indicates poor prognosis hepatocellular carcinoma and the correlation is confirmed through patient-derived xenograft model37. CD44v6, a variation of CD44, when expressed in high level, is associated with short survival time for patient with epithelial ovarian cancer because CD44v6 drives tumor metastasis and drug resistance 38. Because of these characteristics, CD44 presents itself as a good candid for CAR-T cell therapy.

Researchers have tested CD44 directed CAR-T against different types of cancer and the outcome is positive. Experiment conducted by Monica Casucci in 2013 indicates that CD44v6 directed CAR-T could effectively abolish CD44v6+ acute myeloid leukemia and multiple myeloma cells, which are associated with tumor initiation and metastasis 39. The toxicity caused by CAR$\mathrm{T}$ therapy was a concern for the experiment but the researcher proposed a solution: CD44v6 directed CAR-T co-expressing a suicide gene, which would not compromise the efficacy of the treatment but able to have a better control over the side effect39. Recent research using mice model with lung and ovary adenocarcinoma suggests that CD44 directed CAR-T can specifically and efficiently eliminate CD44+ tumor cells than thereby inhibit the development of tumor and increase overall survival rate of the mice40. Another research took a slightly different approach and used minicircle DNAmediated CD44 directed CAR-T against hepatocellular carcinoma33. The result is consistent with the previous ones that CD44 directed CAR-T suppressed hepatocellular carcinoma development in vitro and in vivo while the addition of minicircle DNA enables the therapy to avoid side effect caused by virus33. The effectiveness and specificity of CD44 directed CAR-T therapy reflected through the previous experiment reveal the potential of CD44 as a target for CAR-T therapy across the treatment of various types of cancer.

\section{SUMMARY}

This review presents the potential of using CSC as the target of CAR-T cell therapy and discusses CSC surface markers CD123, CD133 and CD44 directed CAR-T in detail. The CSC contributes to tumorigenic, metastasis, chemoresistance, and relapse and is associated with poor prognosis. When CSCs are eliminated, the development of tumor is inhibited. CD123 is overly expressed in hematologic malignancies while CD133 and CD44 are expressed across various types of cancer. Experiments and trails of CAR-T cell targeting CD123, CD133 and CD44 indicate the specificity and effectiveness of the therapy: cancer cells expressing the targeted CSC surface marker decrease dramatically and the tumors are inhibited. Admittedly, CAR-T cell therapy is still facing multiple challenges and one of the concerns for CSC directed CAR-T is the toxicity41. Scientists have investigated the problem and proposed a possible solution. Previous research tested CD133 directed CAR-T cells with CRISPR/Cas-9 mediated programed cell death protein 1 and the result showed decreased cytotoxicity and enhanced anti-tumor ability42. In summary, these evidences suggest that CSCs directed CAR-T cell therapy might be an effective, practical and safe treatment with limited aversive effect.

\section{REFERENCES}

1. SUBKLEWE, M.; VON BERGWELT-BAILDON, M.; HUMPE, A. Chimeric Antigen Receptor T Cells: A Race to Revolutionize Cancer Therapy. Transfus Med Hemother, v. 46, n. 1, p. 15-24, Feb 2019. ISSN 1660-3796. Disponível em: < https://www.ncbi.nlm.nih.gov/pubmed/31244578>.

2. BRUDNO, J. N.; KOCHENDERFER, J. N. Chimeric antigen receptor T-cell therapies for lymphoma. Nat Rev Clin Oncol, v. 15, n. 1, p. 31-46, Jan 2018. ISSN 1759-4782. Disponível em: < https://www.ncbi.nlm.nih.gov/pubmed/28857075 >.

3. DOTTI, G. et al. Design and development of therapies using chimeric antigen receptor-expressing T cells. Immunol Rev, v. 257, n. 1, p. 107-26, Jan 2014. ISSN 1600-065X. Disponível em: < https://www.ncbi.nlm.nih.gov/pubmed/24329793 >.

4. THANINDRATARN, P. et al. Chimeric antigen receptor $\mathrm{T}$ (CAR-T) cell immunotherapy for sarcomas: From mechanisms to potential clinical applications. Cancer Treat Rev, v. 82, p. 101934, Jan 2020. ISSN 1532-1967. Disponível em: < https://www.ncbi.nlm.nih.gov/pubmed/31794912>. 
5. CAR T Cells: Engineering Patients' Immune Cells to Treat Their Cancers. 2019. Disponível em: < https://www.cancer.gov/aboutcancer/treatment/research/car-t-cells $>$.

6. Kite Pharma, Incorporated, YESCARTA (axicabtagene ciloleucel), [package insert]. U.S. Food and Drug Administration website., Disponível em: < https://www.fda.gov/vaccines-bloodbiologics/cellular-gene-therapy-products/yescartaaxicabtagene-ciloleucel $>$.

7. Novartis Pharmaceuticals Corporation, KYMRIAH (tisagenlecleucel), U.S. Food and Drug Administration website., Disponível em: < https://www.fda.gov/vaccines-blood-

biologics/cellular-gene-therapy-products/kymriahtisagenlecleucel $>$.

8. WANG, Z. et al. New development in CAR-T cell therapy. J Hematol Oncol, v. 10, n. 1, p. 53, 022017. ISSN 1756-8722. Disponível em: < https://www.ncbi.nlm.nih.gov/pubmed/28222796 >.

9. RUELLA, M. et al. Dual CD19 and CD123 targeting prevents antigen-loss relapses after CD19directed immunotherapies. J Clin Invest, v. 126, n. 10, p. 3814-3826, 10 2016. ISSN 1558-8238. Disponível em:

https://www.ncbi.nlm.nih.gov/pubmed/27571406 >.

10. CODD, A. S. et al. Cancer stem cells as targets for immunotherapy. Immunology, v. 153, n. 3, p. 304314, 03 2018. ISSN 1365-2567. Disponível em: < https://www.ncbi.nlm.nih.gov/pubmed/29150846 > .

11. YU, Z. et al. Cancer stem cells. Int J Biochem Cell Biol, v. 44, n. 12, p. 2144-51, Dec 2012. ISSN 18785875. Disponível em: < https://www.ncbi.nlm.nih.gov/pubmed/22981632>.

12. HOUGHTON, J. et al. Stem cells and cancer. Semin Cancer Biol, v. 17, n. 3, p. 191-203, Jun 2007. ISSN 1044-579X. Disponível em: < https://www.ncbi.nlm.nih.gov/pubmed/16762563 >.

13. NANDY, S. B.; LAKSHMANASWAMY, R. Cancer Stem Cells and Metastasis. Prog Mol Biol Transl Sci, v. 151, p. $137-176,2017$. ISSN 1878-0814. Disponível em: https://www.ncbi.nlm.nih.gov/pubmed/29096892 >.

14. BACCELLI, I. et al. Identification of a population of blood circulating tumor cells from breast cancer patients that initiates metastasis in a xenograft assay. Nat Biotechnol, v. 31, n. 6, p. 539-44, Jun 2013. ISSN 1546-1696. Disponível em: https://www.ncbi.nlm.nih.gov/pubmed/23609047 >.

15. ZHAO, J. Cancer stem cells and chemoresistance: The smartest survives the raid. Pharmacol Ther, v. 160, p. 145-58, Apr 2016. ISSN 1879-016X. Disponível em:

https://www.ncbi.nlm.nih.gov/pubmed/26899500 >.

16. STEINBICHLER, T. B. et al. Therapy resistance mediated by cancer stem cells. Semin Cancer Biol, v. 53, p. 156-167, 12 2018. ISSN 1096-3650.
Disponível em: < https://www.ncbi.nlm.nih.gov/pubmed/30471331 > .

17. MUÑOZ, L. et al. Interleukin-3 receptor alpha chain (CD123) is widely expressed in hematologic malignancies. Haematologica, v. 86, n. 12, p. 1261-9, Dec 2001. ISSN 0390-6078. Disponível em: < https://www.ncbi.nlm.nih.gov/pubmed/11726317 >.

18. JORDAN, C. T. et al. The interleukin-3 receptor alpha chain is a unique marker for human acute myelogenous leukemia stem cells. Leukemia, v. 14, n. 10 , p. 1777-84, Oct 2000. ISSN 0887-6924. Disponível em: < https://www.ncbi.nlm.nih.gov/pubmed/11021753 >.

19. TESTA, U. et al. Elevated expression of IL3Ralpha in acute myelogenous leukemia is associated with enhanced blast proliferation, increased cellularity, and poor prognosis. Blood, v. 100, n. 8, p. 2980-8, Oct 2002. ISSN 0006-4971. Disponível em: $<$

https://www.ncbi.nlm.nih.gov/pubmed/12351411 >.

20. MARDIROS, A. et al. T cells expressing CD123specific chimeric antigen receptors exhibit specific cytolytic effector functions and antitumor effects against human acute myeloid leukemia. Blood, v. 122, n. 18 , p. 3138-48, Oct 2013. ISSN 1528-0020. Disponível em: < https://www.ncbi.nlm.nih.gov/pubmed/24030378 >.

21. TETTAMANTI, S. et al. Targeting of acute myeloid leukaemia by cytokine-induced killer cells redirected with a novel CD123-specific chimeric antigen receptor. Br J Haematol, v. 161, n. 3, p. 389401, May 2013. ISSN 1365-2141. Disponível em: < https://www.ncbi.nlm.nih.gov/pubmed/23432359>.

22. PIZZITOLA, I. et al. Chimeric antigen receptors against CD33/CD123 antigens efficiently target primary acute myeloid leukemia cells in vivo. Leukemia, v. 28, n. 8, p. 1596-605, Aug 2014. ISSN 1476-5551. Disponível em: < https://www.ncbi.nlm.nih.gov/pubmed/24504024 >.

23. SUETSUGU, A. et al. Characterization of CD133+ hepatocellular carcinoma cells as cancer stem/progenitor cells. Biochem Biophys Res Commun, v. 351 , n. 4 , p. $820-4$, Dec 2006. ISSN 0006-291X. Disponível em: < https://www.ncbi.nlm.nih.gov/pubmed/17097610 >.

24. ISHIWATA, T. et al. Pancreatic cancer stem cells: features and detection methods. Pathol Oncol Res, v. 24, n. 4, p. 797-805, Oct 2018. ISSN 1532-2807. Disponível em: < https://www.ncbi.nlm.nih.gov/pubmed/29948612>.

25. SINGH, S. K. et al. Identification of human brain tumour initiating cells. Nature, v. 432, n. 7015, p. 396-401, Nov 2004. ISSN 1476-4687. Disponível em: $<$ https://www.ncbi.nlm.nih.gov/pubmed/15549107 >.

26. BRUGNOLI, F. et al. CD133 in Breast Cancer Cells: More than a Stem Cell Marker. J Oncol, v. 2019, p. 7512632, 2019. ISSN 1687-8450. 
Disponível

em: https://www.ncbi.nlm.nih.gov/pubmed/31636668>.

27. LI, X. et al. Prognostic value of cancer stem cell marker CD133 expression in pancreatic ductal adenocarcinoma (PDAC): a systematic review and meta-analysis. Int J Clin Exp Pathol, v. 8, n. 10, p. 12084-92, 2015. ISSN 1936-2625. Disponível em: < https://www.ncbi.nlm.nih.gov/pubmed/26722393 >.

28. LIU, Q. et al. Expression of CD133, PAX2, ESA, and GPR30 in invasive ductal breast carcinomas. Chin Med J (Engl), v. 122, n. 22, p. 2763-9, Nov 2009. ISSN 2542-5641. Disponível em: < https://www.ncbi.nlm.nih.gov/pubmed/19951611 >.

29. NADAL, R. et al. CD133 expression in circulating tumor cells from breast cancer patients: potential role in resistance to chemotherapy. Int J Cancer, v. 133, n. 10, p. 2398-407, Nov 2013. ISSN 1097-0215. Disponível em: https://www.ncbi.nlm.nih.gov/pubmed/23661576>.

30. WANG, Y. et al. CD133-directed CAR T cells for advanced metastasis malignancies: A phase I trial. Oncoimmunology, v. 7, n. 7, p. e1440169, 2018. ISSN 2162-4011. Disponível em: < https://www.ncbi.nlm.nih.gov/pubmed/29900044 >.

31. VORA, P. et al. The Rational Development of CD133-Targeting Immunotherapies for Glioblastoma. Cell Stem Cell, v. 26, n. 6, p. 832844.e6, Jun 2020. ISSN 1875-9777. Disponível em: $<$ https://www.ncbi.nlm.nih.gov/pubmed/32464096 >.

32. ZÖLLER, M. CD44, Hyaluronan, the Hematopoietic Stem Cell, and Leukemia-Initiating Cells. Front Immunol, v. 6, p. 235, 2015. ISSN 1664-3224. Disponível em: https://www.ncbi.nlm.nih.gov/pubmed/26074915 > .

33. WANG, H. et al. Minicircle DNA-Mediated CAR T Cells Targeting CD44 Suppressed Hepatocellular Carcinoma Both in vitro and in vivo. Onco Targets Ther, v. 13, p. 3703-3716, 2020. ISSN 1178-6930. Disponível em: https://www.ncbi.nlm.nih.gov/pubmed/32440140>.

34. WANG, C. Y. et al. The subpopulation of CD44positive cells promoted tumorigenicity and metastatic ability in lung adenocarcinoma. J Chin Med Assoc, v. 82, n. 3, p. 196-201, Mar 2019. ISSN 1728-7731. Disponível em: https://www.ncbi.nlm.nih.gov/pubmed/30908413>.
35. PARTE, S. C. et al. Ovarian Cancer Stem Cells: Unraveling a Germline Connection. Stem Cells Dev, v. 26, n. 24, p. 1781-1803, 12 2017. ISSN 1557-8534. Disponível em: https://www.ncbi.nlm.nih.gov/pubmed/29078734>.

36. HOOFD, C. et al. CD44 promotes chemoresistance in T-ALL by increased drug efflux. Exp Hematol, v. 44, n. 3, p. 166-71.e17, Mar 2016. ISSN 1873-2399. Disponível em: < https://www.ncbi.nlm.nih.gov/pubmed/26708679>.

37. ZHAO, Q. et al. Prognostic value of the expression of cancer stem cell-related markers CD133 and CD44 in hepatocellular carcinoma: From patients to patientderived tumor xenograft models. Oncotarget, v. 7, n. 30, p. 47431-47443, Jul 2016. ISSN 1949-2553. Disponível em: https://www.ncbi.nlm.nih.gov/pubmed/27329727 >.

38. TJHAY, F. et al. CD44 variant 6 is correlated with peritoneal dissemination and poor prognosis in patients with advanced epithelial ovarian cancer. Cancer Sci, v. 106, n. 10, p. 1421-8, Oct 2015. ISSN 1349-7006. Disponível em: < https://www.ncbi.nlm.nih.gov/pubmed/26250934>.

39. CASUCCI, M. et al. CD44v6-targeted T cells mediate potent antitumor effects against acute myeloid leukemia and multiple myeloma. Blood, v. 122, n. 20, p. 3461-72, Nov 2013. ISSN 1528-0020. Disponível em: https://www.ncbi.nlm.nih.gov/pubmed/24016461 >.

40. PORCELLINI, S. et al. CAR T Cells Redirected to CD44v6 Control Tumor Growth in Lung and Ovary Adenocarcinoma Bearing Mice. Front Immunol, v. 11, p. 99，2020. ISSN 1664-3224. Disponível em: < https://www.ncbi.nlm.nih.gov/pubmed/32117253 >.

41. BUENO, C. et al. CD133-directed CAR T-cells for MLL leukemia: on-target, off-tumor myeloablative toxicity. Leukemia, v. 33, n. 8, p. 2090-2125, 082019. ISSN 1476-5551. Disponível em: < https://www.ncbi.nlm.nih.gov/pubmed/30778134 >.

42. HU, B. et al. Nucleofection with Plasmid DNA for CRISPR/Cas9-Mediated Inactivation of Programmed Cell Death Protein 1 in CD133-Specific CAR T Cells. Hum Gene Ther, v. 30, n. 4, p. 446-458, 042019. ISSN 1557-7422. Disponível em: < https://www.ncbi.nlm.nih.gov/pubmed/29706119>. 